higher education levels and lower levels of excessive weight and obesity. This correlation is not causation. Developing countries may encounter the opposite, so it is important for universities in these countries to make health and wellness central to their institutional mission. Developing countries must intensify their efforts to increase student engagement in physical activity programs, a key plank in dealing with an obesity crisis that can only be halted and reversed through education and participation. Developing countries lag behind in regard to economic performance and education levels; in addition, the overall health of their populations will continue to fall behind if educational institutions do not prioritize the health of their students.

DOI: http://dx.doi/org/I0.60I7/ihe.20I7.90.975I

\section{Requiem for a Dream: Academic Freedom under Threat in Democracies}

\section{Daniela Crắciun and Georgiana Mihut}

Daniela Crăciun is a doctoral candidate at Central European University, Budapest, Hungary. E-mail: Craciun_Daniela@phd.ceu.edu. Georgiana Mihut is a doctoral candidate in higher education at the Center for International Higher Education, Boston College, US. E-mail: mihut@bc.edu.

$\mathrm{A}$ cademic freedom is both a core value and a governing principle of higher education institutions. It is so ingrained in research and teaching-especially in democratic states-that it has been taken for granted. More recently, there have been a number of retaliatory actions taken by democratic governments toward academics and higher education institutions.

\section{Academic Freedom and Democratic Govern ments}

In Poland, President Andrzej Duda is threatening to strip a renowned historian of a high state decoration because his work uncovered Polish involvement in the Holocaust. More worryingly, the recently elected right-wing government has proposed legislation that would impose a five-year prison sentence on anybody who imputes that Poland is in any way responsible for Nazi or Stalinist crimes. Hungary fasttracked a legislative amendment to Act CCIV of 20II on National Higher Education that is officially aimed at regulating the 28 international universities that function in the country. However, as observers have noted, it specifically targets one particular international higher education institution that has been immune to traditional tools of influence: Central European University or CEU. So much so, that the law has been dubbed "Lex CEU." CEU played a central role in rebuilding democracy in Central and Eastern Europe and forwarding the ideals of an "open society."

Governments often treat universities akin to political opposition. Since their inception, universities have fostered critical thinking, debate, and —as a result—dissent against the status quo. Traditionally, democratic governments have perceived universities as important and worthy opponents that play a vital role in the metabolism of any healthy democracy. Nondemocratic governments have perceived them as threats and have tried to steer their activities through a variety of means (i.e., curtailing academic freedom, reducing institutional autonomy, cutting funds, closing universities). However, more recently, governments in places generally deemed democratic have started to perceive universities as threats. The recent legislative change in Hungary represents a particularly worrying example.

\section{Academic freedom is both a core value and a governing principle of higher edu- cation institutions.}

\section{Recent Developments in Hungary}

The legislation directly threatens the existence of the university in Hungary. It requires CEU to set up a campus in the state of New York in the United States (where all its programs are registered, but where it does not operate), stops CEU from issuing US degrees to its graduates (even though all its programs are accredited by the Middle States Commission on Higher Education in the United States), imposes work permit vetting by the Hungarian government on CEU faculty from outside the European Union (they are currently exempt from these procedures), and precludes CEU from functioning under its present name.

The Hungarian government argues that the amendment is meant to regulate cross-border higher education programs in order to ensure quality. However, considering that the legislation disproportionately targets $\mathrm{CEU}-\mathrm{a}$ university that ranks 39th in the category of top universities worldwide founded less than 50 years ago (according to the Times Higher Education ranking)-this justification is inapplicable. These are not quality assurance measures, but 
administrative measures intended to give the government direct control over international education, which it previously could not influence through traditional methods (i.e., by cutting public subsidies).

\section{Continuous Attacks on Academic Freedom}

This legislative amendment is the most recent policy initiative targeting academic freedom in the country. Previously, the Hungarian government has employed similar tactics in order to diminish the influence of public universities in the country. In 20I4, another amendment to the national higher education law gave the prime minister the power to appoint chancellors with executive financial responsibilities at public universities. As a result, the power of rectors has been relegated solely to the academic sphere. This arrangement was reinforced by a 2015 amendment to the higher education law, which delegates strategic planning for medium- and long-term goals to university-level advisory bodies mainly comprised of representatives of the national government. The official rationale behind these amendments was to improve the efficiency of publicly funded universities. However, such policies have in fact reduced institutional autonomy and allowed the government to have direct control over university operations.

\section{Academic Freedom in Illiberal States}

These developments were unthinkable just a decade ago. Following the fall of the communist regime in 1989 , Hungary has witnessed a relatively fast and successful transition toward democracy, being among the first Eastern Bloc countries to gain full membership to the European Union (EU). In 20I4, ten years after the EU accession, Prime Minister Viktor Orban declared that in order to protect Hungary's national sovereignty, he planned to abandon liberal democracy in order to establish an "illiberal state" modeled after the realities of Russia and Turkey. According to The Economist Intelligence Unit's Democracy Index, which measures indicators such as the quality of political participation and political culture, since 20II Hungary has become an ever clearer "flawed democracy."

Severe assaults on academic freedom have taken place in Russia and Turkey. In Russia, the European University at St. Petersburg (EUSP) has had its educational license revoked after a complaint by politician Vitaly Milonov triggered II unannounced inspections from regulatory agencies that uncovered I2O licensing violations, only one of which has not been resolved. Incidentally, Vitaly Milonov is the architect of the ill-famed law banning "gay propaganda" and EUSP is home to the biggest gender studies center in the country. In Turkey, Scholars at Risk reports that almost 6,000 academic and administrative personnel have been dismissed from universities by authorities, based on sus- picions that they were involved in the 2016 failed coup attempt.

\section{CONCLUSION}

Attacks on academic freedom in democratic countries are both a powerful indicator and a consequence of democratic decline. The protection of academic freedom represents an important societal tool for inclusiveness and guards against power abuses. Countries such as Hungary have witnessed firsthand the devastating effects of authoritarian regimes. Teaching freely and researching freely ensure that history is not forgotten, and that the checks and balances necessary for a working democracy are maintained. Academic freedom is important not only for the wellbeing of universities, but also for the wellbeing of the countries and regions in which they operate.

DOI: http://dx.doi/org/ro.6or7/ihe.20I7.90.9929

\section{Ukraine: Endemic Higher Education Corruption}

\section{Elena Denisova-Schmidt and Yaroslav Prytula}

Elena Denisova-Schmidt is lecturer at the University of St. Gallen, Switzerland, and research fellow at the Center for International Higher Education at Boston College, US. E-mail: elena.denisova-schmidt@ unisg.ch. Yaroslav Prytula is dean of the Faculty of Applied Sciences at the Ukrainian Catholic University, Lviv, Ukraine.E-mail: ya.prytula@ ucu.edu.ua.

$\mathrm{R}$ ecent articles in the Wall Street Journal and The Times of London raise the alarm: international students enrolled at US and UK universities cheat more frequently than their domestic counterparts. Why does this happen? Using Ukrainian higher education as an example of an endemically corrupt academic environment, we try to answer this question by exploring some determinants of student academic misconduct, and provide insights on groups of students who are more likely to engage in either monetary or nonmonetary corruption. Our findings might help American and European universities hosting international students to adjust their policies and procedures with regard to academic integrity.

\section{Why UKRAINE?}

In Ukraine, as in most post-Soviet countries, corruption in higher education is not an exception, but rather a growing 